$$
e=1-\frac{g}{a}
$$

де $g$ - перигельна відстань; $a$ - велика відстань (в астрономічних одиницях). Порівнюємо отриманий результат із табличним ( $e=0,055)$.

7. Робимо висновки про рівномірність руху Місяця по орбіті.

8. Коли можна спостерігати ділянку зворотного боку Місяця? Чому це можливо?

9. Висновки.

Ефективність астрономічних спостережень $є$ цілком очевидною, оскільки саме такий вид діяльності студента сприяє не тільки засвоєнню навчального матеріалу, а й дисциплінує особу, яка навчається, виробляє силу волі, бажання самому одержати правильний результат шляхом експериментальних здобутків.

Астрономічні спостереження підвищують у студента зацікавленість предметом, викликають потребу в знаннях, сприяють свідомому й міцному оволодінню матеріалом, надають переконливості сформованим поняттям та явищам.

\title{
Література
}

1. Соколова I. В. Професійна компетентність вчителя: проблема структури та змісту / І. В. Соколова // Неперервна професійна освіта: теорія і практика: Науково-методичний журнал. - 2004. - Вип. 1. С. 8-16. 2. Хуторской А. В. Ключевые компетенции и образовательные стандарты // А. В. Хуторской. - Интернет-журнал «Эйдос». -2002.

\section{ФОРМУВАННЯ МОВНОЇ ТА МОВЛЕННСВОЇ КОМПЕТЕНТНОСТІ УЧНІВ ОСНОВНОЇ ШКОЛИ}

У статті показано особливості мовно-мовленннєвої підготовки учнів основної школи у процесі застосування інновачійної лінгвометодичної технології «Інтеракція різнотипових підходів до вивчення мови»; з'ясовано актуальність проблематики $і$ завдання наукового дослідження, методоло- 
гічні засади зіставлення навчальних дій у чотирьох видах мовленнєвої діяльності; з'ясовано окремі дефініції терміна «підхід» $i$ виведено власне трактування иього поняття в методиці навчання мов; описано систему пропедевтичного вивчення словосполучення в п'ятому класі в руслі поєднаного використання таких підходів, як комунікативно-діяльнісний, особистісно зорієнтований, сочіокультурний, текстоцентрично-дискурсний, компетентнісний.

Ключові слова: мовно-мовленннєва підготовка, інтеракиія різнотипових підходів, інтерактивне навчання, когнітивна методика, комунікативно-діяльнісний, особистісно зорієнтований, соціокультурний, текстоцентрично-дискурсний, компетентнісний.

В статье показаны особенности учебной роботы над языковым и речевым материалом с учениками основной школь при применении инноваиионной лингвометодической технологии «Интеракиия различновидовых подходов к изучению языка»; раскрыта актуальность проблемы и задания научного исследования; методические основы сопоставления учебных действий в ходе изучения единиц языка и их употреблении в четырех видах речевой деятельности; конкретизировано понятие термина «подход»; описана система поэтапного изучения словосочетания в пятом классе по новой методике с использованием взаимосвязи таких подходов, как коммуникативно-деятельностный, личностно-ориентированный, соичиокультурный, текстоиентрически-дискурсивный и компетентностный.

Ключевые слова: языковая и речевая подготовка, интеракиия разновидовых подходов, интерактивное обучение, когнитивная методика, коммуникативно-деятельностный, личностно-ориентированный, социокультурный, текстоцентрически-дискурсивный, компетентностный.

The article deas with the basic school students' speech training peculiarities during the process of application of the innovative linguistic and methodical technology "The polytypic approaches interaction for learning Ukrainian language». The actuality, the tasks of the research and methodical basis educational actions confrontation in four types of speech activity are found out. Some definitions for "approach» and the own interpretation of this term are indicated; the system of the word combination poetic studying at the fifth year in the way of the combination of such approaches as communicative and active, personality oriented, social and cultural, text centered and competent.

Key words: speech training, interaction, linguistic and methodical technology, approach, word combination poetic studying.

Останнім часом у науково-методичних публікаціях учених та вчителів все частіше звертається увага на використання у шкільній практиці різноманітних підходів до вивчення української мови як рідної і як державної. Попри таке активне висвітлення проблема застосування ефективних підходів до навчання української мови і далі залишається відкритою, не дослідженою, що, відповідно, зумовило актуальність теми нашого повідомлення. 
У сучасній лінгводидактиці описано системнокомплексний (3. Бакум, О. Біляєв, С. Караман, В. Мельничайко, К. Плиско, Г. Кирилова), функціональностилістичний (М. Пентилюк, П. Кордун, В. Мельничайко, А. Нікітіна, В. Новосьолова, Л. Паламар, Л. Мацько, I. Лопушинський, Г. Дідук), комунікативно-діяльнісний (А. Богуш, М. Вашуленко, Л. Варзацька, М. Пентилюк, Т. Донченко, Н. Голуб, О. Горошкіна, 3. Бакум, Л. Скуратівський, Г. Дідук, О. Хорошковська, Г. Шелехова, Ю. Пассов, С. Ніколаєва, В. Бадер, Т. Окуневич, С. Омельченко, О. Глазова, Д. Кобцев, В. Статівка. Г. Михайловська, В. Голобородько, В. Капінос, А. Купалова, Л. Паламар, Е. Палихата, Н. Пашковська та ін.), соціокультурний, культурологічний (В. Дороз, В. Кононенко, Г. Дідук, Ж. Горіна, Д. Кобцев, Н. Остапенко, Ю. Пассов. Г. Селевко, В. Телія, Н. Мішатіна, Н. Арутюнова, В. Красних, М. Вугат, B. Baers, Л. Кузьміна та ін.), когнітивний (3. Бакум, М. Пентилюк, О. Горошкіна, В. Дороз, А. Нікітіна, Г. Дідук, С. Караман, О. Караман, Ю. Романенко, Н. Мішатіна, I. Зимня, Ю. Караулов, О. Леонтьєв, В. Маслова, Ю. Степанов та ін.), особистісно зоріснтований, антропоцентричний (А. Богуш, О. Глазова, М. Вашуленко, О. Савченко, О. Хорошковська, Г. Дідук-Ступ'як, Т. Окуневич, Г. Шелехова, І. Хом'як та ін.), компетентнісний (А. Богуш, Л. Мацько, С. Караман, О. Глазова, О. Горошкіна, Н. Голуб, Г. Дідук-Ступ'як, Л. Морська, Т. Симоненкова та ін.), текстоцентрично-дискурсний (Л. Мацько, Л. Варзацька, Н. Голуб, О. Горошкіна, М. Пентилюк, Т. Донченко, Г. Дідук-Ступ'як, Н. Остапенко, Ю. Романенко, Г. Шелехова та ін.).

Важливим для нашого дослідження було з'ясувати концептуальну термінологію, якою послуговуватимемося у статті. Дефініції цих термінів є неоднозначними і багатогранними, тому спершу подамо деякі із визначень, запропонованих науковцями, які прямо й опосередковано зверталися до цього питання.

Методист Е. Ентоні вважає, що «підхід до навчання мови» - це «...сукупність взаємопов'язаних і взаємозумовлених уявлень про природу мови і процес оволодіння нею» [12, c. 63].

Згідно з основними вихідними положеннями інноваційних педагогічних технологій, дослідник Г. Селевко трактує «під- 
хід» як комплексний педагогічний засіб, що містить три основні групи таких елементів:

- основні поняття, що використовуються в процесі навчання, які є головним інструментом мисленнєвої діяльності;

- принципи як вихідні положення або головні правила здійснення педагогічної діяльності;

- методи і прийоми побудови освітнього процесу [11, c. 71].

Важливим для нашого дослідження $є$ міркування В. Дороз, що «підхід означає загальну вихідну концептуальну позицію, яка є вирішальною в розгляді та визначенні інших підпорядкованих концептуальних положень, тобто, це стратегія навчання» [7, с. 14]. Підсумовуючи зазначене вище, подаємо своє трактування цього поняття. На нашу думку, niдxid до вивчення мови є стратегічною концентричною системою, яка містить такі прочесуально-змістові складники, як: закономірності, принципи, форми, методи і прийоми роботи з мовно-мовленнєвим матеріалом і сприяє формуванню україномовної висококультурної, духовно багатої особистості.

Проблема розвитку учнів загальноосвітніх шкіл, удосконалення їхньої як загальної, так і національної мовномовленнєвої культури набуває актуальності у зв'язку з необхідністю піднесення національної самосвідомості українського народу.

Важливою проблемою, що вимагає постійної уваги, є проблема вдосконалення мовної освіти. Національна школа є однією 3 основних державних інституцій, покликана розв'язувати завдання становлення i розвитку української мови. Завдання проблеми, поставленої у статті, зумовлюються процесом реформування національної освіти, піднесенням ролі української мови і культури в суспільстві, які нерозривно пов'язані, адже загальна культура нації вирішальною мірою залежить від рівня володіння мовою та мовною культурою, тих важливих чинників, які бережуть і творять національну духовність й національну культуру. У зв'язку з цим сучасна школа потребує розроблення і впровадження таких підходів до опанування мовно-моленнєвим матеріалом, які би відповідали потребам розвитку висококультурної мовної особистості, сприяли розкриттю їі духовно-емоційних, комунікативно-розумових здібностей [10, с. 32].

Створення умов для формування такої україномовної, духовно багатої мовної особистості є одним із важливих завдань 
навчання української мови учнів загальноосвітніх шкіл. Це завдання, на нашу думку, слід реалізувати через поєднання ряду підходів до вивчення української мови, які сприятимуть становленню в учнів уявлення про мислення і мовлення, світ, природу, суспільство, ознайомленню їх з основним культурним набутком рідного народу і людства, розвиткові духовної сфери особистості, зокрема моральних переконань, відчуття прекрасного тощо.

Мета статmi - розкрити роль технології «Інтеракція різнотипових підходів до вивчення мови» у процесі мовномовленнєвої підготовки учнів основної школи.

Характер цієї лінгводидактичної технології зумовлює необхідність реалізації іï не лише на спеціальних уроках розвитку мовлення, а й на заняттях вивчення мовного матеріалу.

Сучасний стан вивчення рідної мови передбачає навчання мови і мовлення не за допомогою окремих ізольованих речень, а на основі текстів різних типів і стилів.

3 огляду на це важливо, щоб у процесі застосування комунікативно-діяльнісного, особистісно зорієнтованого, соціокультурного (культурологічного), текстоцентрично-дискурсного, компетентнісного підходів до вивчення кожної мовної теми розпочиналося вправами, які будуються на матеріалі зв'язних текстів, орієнтовна тематика яких представлена у новій програмі 3 рідної мови [10]. Отже, створюються об'єктивні умови для розгляду мовних явищ в їх взаємозв'язках, у контексті словесної творчості. Зв'язний текст при цьому виступає засобом створення мовленнєвих ситуацій, активізації пізнавальної діяльності учнів. До кожного блоку уроків, об'єднаних спільною соціокультурною темою, добираються тематично побібні тексти. Робота над змістом, структурою, мовним оформленням цих текстів надає змогу розв'язати низку комплексних завдань, зокрема, вивчати конкретні мовні явища, розвивати словесну творчість дітей у руслі пропонованої теми. Тематику текстів розроблено так, щоб рідне слово стало засобом долучення учнів до духовної культури народу. «Тільки засвоївши думку й почуття, що створили форми мови, дитина справді опановує цю форму і в цій формі дістає ключ до скарбниці народного духу» $[5$, c. 195$]$.

Тексти слугують своєрідним емоційно-образним унаочненням для пізнання законів мови. Завдяки цьому розвивається думка, активізуються бажання вчитися. Ефективне за- 
своєння мовної і мовленнєвої теми безпосередньо залежить від опори на текст, всебічного і послідовного використання його культурологічних, розвивальних і дидактичних функцій. Важливим прийомом організації навчання рідної мови через розв'язання мовленнєвих завдань $є$ добір текстів до уроків рідної мови й мовлення, об'єднаних спільною тематикою.

Освітнє наповнювання технології «Інтеракція різнотипових підходів» становить систему текстів і усних висловлювань, зміст яких у своїй основі грунтується на вже засвоєних учнями відомості з різних предметів (історії, географії, літератури, іноземних мов, предметів мистецького циклу тощо) i віддзеркалює національну культуру українського народу, а також кращі зразки світової літератури.

Взаємозв'язок комунікативно-діяльнісного, соціокультурного, текстоцентрично-дискурсного підходів допомагає у формуванні мовних і мовленнєвих умінь та навичок в учнів. Ми пропонуємо вивчати граматичні, правописні норми на основі текстів різних жанрів, стилів і типів. Текст, будучи одиницею мовлення, сприяє розкриттю конкретної тематики, що містить певну пізнавальну проблему, в основу якої покладено суперечність між життєвим досвідом учнів і відомостями, що відображені у змісті текстів [1, с. 18].

Відповідно до нової програми 12-річної школи учні повинні вміти слухати текст і розуміти його, усвідомлювати тему та основну думку, логіку викладу, провідний тип мовлення (розповідь, опис, роздум), стиль мовлення, особливості авторського стилю; відтворити почуте в переказі з урахуванням його виду та особливостей типу i стилю мовлення; запам'ятовувати конкретні факти, послідовність викладу матеріалу, підбирати репліки і будувати діалоги. Під час роботи над переказами у 5-х класах автори підручників і методичних рекомендацій до них основну увагу приділяють структурі тексту, логічному і мовному оформленню. Увага учнів і вчителя сконцентровується на вирішенні питань: вміння розкрити тему і основну думку, передати з точністю матеріал тощо.

Відбір дидактичного матеріалу та різні види роботи 3 ним мають допомогти дітям усвідомити мову як матеріал передачі думки й змісту, відчути красу слова, виховати потребу в творчості, прагнення до точності, виразності, образності власного мовлення, намагання додержуватися норм у використанні мовних одиниць різних рівнів мовної системи, бажання навчитись майстерно оперувати мовою. 
Кожен урок рідної мови - складна, цілісна, динамічна система змісту навчального матеріалу й організації роботи 3 ним, яка насамперед спрямовується на засвоєння матеріалу, зазначеного в темі уроку. Мета уроку й мета організації уроку - різні за обсягом поняття. Мета уроку збігається з метою навчального процесу в цілому. Модель уроку рідної мови має забезпечити реалізацію комплексу навчальних цілей, формування всебічної національно-мовної особистості. Реалізація навчальних цілей великою мірою залежить від вибору дидактичних засобів. Як правило, при цьому не йдеться про підручники, посібники та про засоби наочності, які містять лише інтерпретований дидактичний матеріал. Тому насамперед слід говорити про принципи відбору і використання дидактичного матеріалу [9, с. 5].

Навчання рідної мови ефективне, якщо на кожному уроці засвоюються мовні й мовленнєві знання, формуються навчально-мовні, правописні та комунікативні вміння й навички, розширюється читацький рівень учнів (рскільки дитина, яка більше читає, краще говорить і пише), збагачується їхній мовний запас, відбувається оволодіння мовною нормою, здійснюється усвідомлення неповторності мовної особистості. Учні одержують зразки комунікативно досконалої мови й навчаються доцільно і правильно використовувати засоби мови для побудови власних висловлювань, а також набувають найрізноманітніших загальнопредметних умінь.

Рідній мові належить особлива роль у вихованні школярів. Згадаймо, як зазначав В. Сухомлинський: «Від культури слова до емоційної культури, від емоційної культури до культури моральних почуттів і моральних відносин - такий шлях до гармонії знань і моральності»; «Убогість слова - це убогість думки, а убогість думки веде до моральної, інтелектуальної, емоційної, естетичної товстошкірості» [4, с. 57].

Навчання рідної мови забезпечує інтенсивніший порівняно $з$ традиційним розвиток мовної особистості лише за умови системноцілісного підходу до реалізацій навчальної мети. Остання істотно впливає на мотив навчальної діяльності, оскільки сприяє урізноманітненню навчальних дій, що в свою чергу запобігає втомі, викликає інтерес, активізує діяльність учнів i, як показують експерименти, підвищує ефективність навчальної діяльності.

Модель сучасного уроку української мови вченіметодисти пропонують таку: визначення мети організації 
уроку $\rightarrow$ аналіз навчального матеріалу $\rightarrow$ визначення проміжних цілей $\rightarrow$ відбір дидактичного матеріалу $\rightarrow$ визначення супровідних цілей $\rightarrow$ планування видів діяльності і навчальних дій $\rightarrow$ побудова завдань $\rightarrow$ організація виконання завдань i, відповідно, видів діяльності i навчальних дій $\rightarrow$ результати [6, с. 33].

Розглянемо на прикладі за вказаним типажем як організовується навчально-виховна діяльність учнів у процесі застосування технології «Інтеракція різнотипових підходів до вивчення мови» і як відбувається засвоєння лінгвістичних понять, які існують варіанти методичної організації такої діяльності, як здійснюється ознайомлення зі структурою поняття, як вирізняються основні ознаки поняття, факту мови та мовлення.

Для опису покрокових дій розробленої нами технології взято тему «Загальне поняття про словосполучення», яка була проведена в контрольному й експериментальному 5-х класах. Зміст навчального матеріалу з цієї теми містить значення та структуру словосполучень, правила їх побудови й використання у мовленні як будівельної одиниці речення. Учні мають засвоїти, що словосполучення, як і слово, виконує називну (номінативну) функцію, тобто називає предмети, ознаки, дії в їх відношенні до інших предметів, ознак, дій, дає змогу конкретніше, ніж окреме слово, назвати предмет, ознаку, дію, виділити їх з ряду подібних. Ця функція забезпечується структурою словосполучень. 3 погляду структури словосполучення $\epsilon$ поєднанням двох або кількох слів, пов'язаних за змістом i граматично. Смисловий зв'язок встановлюється за допомогою питання, граматичний зв'язок - за допомогою закінчення або закінчення та прийменника. Словосполучення $є$ будівельним матеріалом речення й служить для поширення непоширених речень $з$ метою повнішого, точнішого, яскравішого, переконливішого висловлення думки.

Зміст поняття визначає також той обсяг умінь, яким повинні оволодіти учні: відрізняти словосполучення від інших сполучень слів (слово та прийменник, сполучення підмета та присудка, однорідних членів речення); вилкремлювати словосполучення із речення; визначати і будувати різні типи словосполучень тощо.

Першим кроком експериментальної методики на уроці була конкретизачія значення словосполучень із використан- 
ням наочності - картин. Методом евристичної бесіди актуалізуємо знання учнів:

- Уваюнно подивіться на картини, - каже вчитель. - Що на них зображено?

- Лic.

- Якийліс на периій картині?

- Осінній ліс.

- На другій?

- Зимовийліс.

Запишемо: «Ліс. Осінній ліс. Зимовий ліс». Що точніше виражає зміст картини: слово чи словосполучення?

- Словосполучення дають змогу більш точно і конкретно, ніж окреме слово, назвати предмет, бо називають не тільки предмет, а $i$ його ознаку.

Увага учнів спрямовується на усвідомлення змістового зв'язку між словами в словосполученні.

- Чи можна побудувати словосполучення зі слів "любити» й "будівля" «зошит" $i$ «буряк».

- 3 чих слів побудувати словосполучення не можна, бо вони змістовно не пов'язані.

- А зі слів «читати» й «книюкка», «брат» $\boldsymbol{i}$ «сестра»?

- «Читати книжску, брат із сестрою»,

- Коли з двох слів можна побудувати словосполучення?

- Коли иі слова пов'язані за змістом.

3'ясовується граматична структура словосполучень:

- А як ми визначаємо наявність смислового зв'язку між словами в словосполученні?

- Ставимо запитання від одного слова до другого.

- Отоже, словосполучення складається з головного слова $i$ залежного. Те слово, від якого ставиться запитання, є головним, те, яке відповідає на запитання, - залежним.

Учитель показує, як графічно позначається смисловий i граматичний зв'язок між словами у словосполученні.

Встановлюються засоби граматичного зв'язку між словами у словосполученні.

- Що відбулося з одним із слів, коли ми поставили до нього запитання?

- У ньому змінилось закінчення (закінчення в залежних словах виділясться).

- Що ще, крім закінчення, ми використали, коли утворили словосполучення «брат із сестрою»?

-Прийменник. 
- Закінчення слів, прийменники, їх роль у мові вивчаються в граматиці. Тому зв'язок залежного слова з головним за допомогою закінчень і прийменників називається граматичним.

- А як пов'язані слова в словосполученні «бігти швидко»?

- Лиме за змістом.

- Отоже, якщо залежсне слово - прислівник, то воно пов'язується

з головним лише змістовно.

Учитель пропонує учням, використовуючи елементи комунікативно-діяльнісного, текстоценрично-дискурсного i компетентнісного підходів, узагальнити все те, що вони дізналися про словосполучення, та скласти висловлювання на тему «Словосполучення».

Організовується також робота, спрямована на розвиток у п'ятикласників уміння виокремлювати словосполучення 3 речень, а також на усвідомлення ними того, що сполучення підмета й присудка не є словосполученням, оскільки між ними відсутній підрядний зв'язок. Для цього застосовуємо елементи комунікативно-діяльнісного і компетентнісного підходів, проводячи пізнавальну бесіду:

- Скільки словосполучень у реченні «Граки в ють гнізда на високих деревах»?

- Чотири.

- Знайдіть граматичну основу в реченні.

-Граки в'ють.

- Чи є серед цих слів головне й залежне?

- Між підметом і присудком підрядний зв'язок відсутній, тому вони не можуть бути словосполученням. Відтак, з поданого речення може бути виділено тільки три словосполучення.

Уміння виокремлювати словосполучення необхідне для написання багатьох орфограм. Визначити в словосполученні відмінок іменника можна від залежного слова, наприклад: Ложка (дьоготь) зіпсує бочку меду. У кого совісті нема, нема й (сором). Раді люди (літо), а бджсоли (ивіт). Без уміння виокрмелювати словосполучення немислимо навчити учнів правильно писати голосні у відмінкових закінченнях іменників. Зразок міркування:

-Стояти над кручею. Головне слово «стояти». Стояти над чим? - Орудний відмінок. Отже, в закінченні буде «є», як $i$ в орудному відмінку іменників I відміни.

Наступним кроком інтеракції комунікативно-діяльнісного, особистісно зорієнтованого, соціокультурного і текстоцентрично-дискурсного підходів $\epsilon$ виконання пошуково- 
пізнавальних завдань проблемно-дослідного характеру, які тренують учнів виокремлювати орфограми при створенні зв'язних висловлювань. Діти набувають уміння визначати вид словосполучень, будувати словосполучення, якими можуть бути поширені пропоновані речення тощо. Когнітивна методика розвиває при цьому також і операційну здатність. Так, щоб визначити вид словосполучення, учень повинен: 1) поставити запитання від одного слова до іншого; 2) визначити головне та залежне слова; 3) установити, якою частиною мови $є$ головне слово. Щоб, наприклад, утворити словосполучення зі значенням предмета, потрібно: 1) дібрати слово зі значенням предмета; 2) установити його зв'язок 3 іншими словами; $3)$ поставити питання від слова, яке означає предмет, до слова зі значенням ознаки; 4) правильно вжити форму залежного слова. Крім того, певні операції учень виконує, коли робить граматичний розбір.

Отже, на цьому уроці здійснюємо мовно-мовленнєву підготовку під час якої реалізуємо різні підходи, що сприяють ефективному засвоєнню поняття про словосполучення, повторюємо навчальний матеріал, проводимо орфографічну роботу, формуємо операційну здатність учнів, розвиваємо мовлення, інтелект, логічне мислення, емоційну сферу. Подивимось на цей урок ще й з погляду оволодіння комунікативними вміннями. Як відомо, найбільшу складність становить монологічне мовлення - слухати монолог, читати монолог, будувати монологічне висловлювання в усній і письмовій формах. Така робота на уроці проводиться не належним чином. Досягнення мети організації уроку, формування комунікативних умінь залишається пріоритетом уроків розвитку зв'язного мовлення. Обмежена кількість уроків розвитку зв'язного мовлення, які нами ще визначені як уроки формування комунікативно-мовленнєвих умінь і навичок, не дає змоги дати дітям потрібної кількості текстів-зразків і тим більше організувати ïх аналіз 3 огляду використання мовних засобів. Спостереження за навчальним процесом у школі переконують, що на уроках розвитку зв'язного мовлення надзвичайно мало уваги приділяється роботі над відбором мовних одиниць. Розв'язання цієї проблеми може бути знайдене тільки при використанні технології «Інтеракція різнотипових підходів» до вивчення мовних одиниць на основі аналізу тексту в єдності змісту й форми. 
Отже, зіставлення сукупності навчальних дій і видів навчальної діяльності свідчить про те, що дозоване і вдале поєднання різних підходів допоможе ефективно і концентровано вивчати мовні елементи різних рівнів у чотирьох видах мовленнєвої діяльності; також у процесі описаної роботи досягається ефективне сприйняття учнями 5 класу на різних етапах уроку кількості навчальних цілей, що врешті-решт сприяє розвитку інтелектуальних та практичних умінь і навичок. Результати проведеного формувального експерименту дозволяють зробити висновки, що організувати велику кількість навчальних дій і видів діяльності можливо у процесі інтеракційного вивчення мовних одиниць на основі аналізу тексту в єдності змісту і форми. Технологія «Інтеракція різнотипових підходів до вивчення мови» допомагає покращити роботу 3 текстом, надає змогу урізноманітнювати навчальні завдання, а, отже, реалізувати більше цілей i, що дуже важливо, дати учням мовленнєві зразки, тісніше поєднати цілі вивчення лінгвістичних тем і розвиток зв'язного мовлення учнів, формувати разом із засвоєнням понять і правил мовленнєвокомунікативні вміння, систематично проводити роботу з розвитку мовлення. На одному і тому самому уроці у процесі аналізу тексту учні засвоюють мовні одиниці й правила, набувають різноманітних комунікативних умінь, усвідомлюють особливості відбору мовних одиниць у конкретному мовленнєвому спілкуванні, будову текстів, жанрово-стилістичні, логіко-композиційні й понятійно-змістові ознаки різних типів мовлення.

Описана лінгвометодична інноваційна технологія «Інтеракція різнотипових підходів до вивчення української мови», що може бути використаною на уроках української мови у процесі мовно-мовленнєвого іiї вивчення, не вичерпує всіх аспектів цієї важливої проблеми. До перспективних напрямків подальшого наукового пошуку в галузі дослідження можна віднести питання застосування вказаної педагогічно-освітньої технології у процесі навчання аудіюванню та виразному читанню при опануванні української мови як рідної і як державної.

\section{Література}

1. Білясв О. М. Концепція національної державної мови в школах України / О. М. Біляєв, Л. В. Скуратівський, Л. М. Симоненкова, Г. Т. Шелехова // Дивослово. - 1996. - № 1. - С. 16-22. 2. Дідук Г. І. Комунікативно-функціональний аспект вивчення словосполучення 
i речення у 5-8 класах / Галина Іванівна Дідук // Науковий вісник Південноукраїнського державного педагогічного університету ім. К. Д. Ушинського : [зб. наук. праць]. - Випуск 2. - Одеса : ПДПУ ім. К. Д. Ушинського, 2000. - С. 49 -53. 3. Дідук Г. І. Конструювання та метод редагування в комунікативнолінгвостилістичній роботі під час вивчення займенника у 6-му класі / Галина Іванівна Дідук // Наукові записки Тернопільського державного педагогічного університету імені Володимира Гнатюка. Серія: Педагогіка. - 2002. - № 8. - С. 95-99. 4. Дідук Г. І. Реалізація когнітивного принципу навчання у процесі комунікативнолінгвостилістичної роботи на уроках української мови / Галина Іванівна Дідук // Наукові записки Тернопільського державного педагогічного університету імені Володимира Гнатюка. Серія: Педагогіка. Лінгводидактика. - 2004. - №1. - С. 56-59. 5. Дідук Г. І. Проблема інтеракції комунікативно-функціонального i компетентнісно-орієнтованого підходів у чинних програмах і підручниках / Галина Іванівна Дідук // Наукові записки Тернопільського національного педагогічного університету імені Володимира Гнатюка. Серія: Педагогіка. Лінгводидактика. - 2007. - № 9. - С. 194-199. 6. Донченко Т. Два уроки на одну тему / Тамара Донченко // Дивослово. - 1996 - № 9. - С. 32-34. 7. Дороз В. Сучасні культурологічні підходи до навчання учнів-білінгвів другої мови / Вікторія Дороз // Українська мова і література в школі. 2010. - № 3. - С. 14-18. 8. Пассов Е. И. Коммуникативное иноязычное образование: концепция развития индивидуальности в диалоге культур / Е. И. Пассов. - Липецк : Липецк. гос. пед. ин-т, 1998. 159 с. 9. Пентилюк М. Концепція когнітивної методики навчання української мови / Марія Пентилюк, Алла Нікітіна, Олена Горошкіна // Дивослово. - 2004. - № 8. - С. 5-9. 10. Програма для загальноосвітніх навчальних закладів. Українська мова 5-12 класи / за ред. Скуратівського Л. В. - К. : - Ірпінь, 2005. - 136 с. 11. Селевко Г. К. Энциклопедия образовательных технологий $(\mathrm{Ce}-$ рия «Энциклопедия образовательных технологий») / Герман Константинович Селевко. - М.: Флинта-Наука, 2006. - С. 71. 12. Anthony E. M. Approach, method and teaching // English Language Teaching. - London, 1963. - Vol. 17. - P. 63-67. 13. Byram M. Westigation studies in foreign language teaching clevedon: Multilingual Mateers ltd., 1991. - P. 8-17. 14. Byram M. and Zarat G. Definitions, objectives and assessment of sociocultural competence // A Common European Framework for Language Teaching and Learning. Strasbourg: Council of Europe Press, 1994. - P. 19. 